\title{
Men Walk on Moon: A Powdery Surface Is Closely Explored · Ben Groff
}

REGARDING MY FATHER, Ernest Hopf, Sr., I would like to clearly state that this imperfect man was drawn by the light of reason. He had only one problem: He walked on the moon.

I'm not suggesting, of course, that he was an astronaut, although it might have been simpler if he were. It is never simple to become something other than what you were meant to be, and he was meant for a different planet, where dispassionate eyes confirmed the truth of all they beheld, and communications passed calmly through an airless void in terms such as "roger" and "we read you," and - perhaps - there were no children. Or, if there were, they did not have sex in the family room with their seventeenyear-old girlfriends. My father was intelligent and adaptable, he could deal with many things, but the naked vision of Mimi and me in consummate sublunary embrace was not one of them. Victoria says this was the primal scene in reverse. She says no man can begin to accept the fact that his own son is exactly the same as himself, an animal. She says that a woman is always a mother but a man is a child until his child is born, and then he becomes something close to an abstraction, and an empty one at that - the law he never loved - and all his efforts on the child's behalf, all his spankings and his teachings and his hopes and expectations for the future, boil down to one rule: that the child shall never know the man at all.

Victoria says things like this all the time. It's her job (she's a counselor) but I'm not convinced. Neither is Ruth, my recently estranged wife. Always a mother, that's rich, Ruth says with a sneer, which, while we were married, was the one weapon she never allowed herself. She says that as far as she knows Victoria's childless - not counting me. And against Victoria, I myself must say that, on the contrary, my father loved the law very much. Where the law was concerned, he had a kind of scientific passion. Not that he sat on the bench, or was an attorney. I don't mean anything that literal, just that the exercise of judgment gave him an almost physical thrill. He believed in judgment. If he had been alive when Rusty smuggled Shyla into our bedroom and rutted and rolled beneath the bizarre comforter Ruth had long since laid on our bed like a malediction, 
he would have felt no ambivalence. He would have acted, decisively, and it would probably have been for the better. He was strongly imbued with the puritanical form of idealism.

To which Victoria says: precisely her point. And as for the rest of it, especially as regards my own son Rusty and me, $I$ believe in Victoria. The child shall never know the man at all. If Rusty had known the first thing about his father, he might have forgiven me, instead of going off the deep end and eloping with Shyla, this beautiful Shyla, and getting married at the tender age of eighteen.

I don't really see how it could have happened, when I'd told him everything. Maybe I never put it properly. There's a way of speaking that Victoria calls crayon language. She says it is blunt, thick, colorful, and entirely non-toxic. She says it should not be used on interior walls but is suitable for drawing the big picture with small hands. It's not my natural mode of expression, but as the children's librarian here in Laguna Beach, I know what she's getting at. Victoria, by the way, is into dysfunctional family, male self-integration, and griefwork. So am I. She says it's important to achieve a communication, so just sit back while I pick up my crayons and color.

Let's start with sky-blue-pink.

My father was a newspaperman, and when I was small that word seemed to capture and to hold, as a small glass ball held up will hold the sky, clouds and all, everything he was. In the mapled light of a small-town Pennsylvania evening, he would walk up the driveway from the train station, home from the Bulletin in his suit and tie, with his pants billowing from his long steps, his hands in his pockets and the paper folded under his arm, and somehow it wasn't so much my father who brought the paper home, as the paper that brought my father home to me.

Other people's fathers carried papers, perhaps even less inconspicuously than he did, but never with the same ineffable air of pride and dread. I have an old snapshot, black and white with scroll-cut edges, in which he holds a diapered me uncertainly to the camera. He is not so young as you'd think a new father might be, and the frames of his glasses, black and unsubdued, enhance this impression. He is not smiling, but he is not frowning, either. $\mathrm{He}$ is cautiously considering an act of desperation. The memory or presentiment of this act struggles at depth with what can be seen of his charac- 
ter, and oddly enough there was something of the same tension in the way he had of carrying the newspaper-like it was a part of himself he didn't fully trust, born out of desperation and inevitably leading back to it again. It was as if it were his other child, though obviously I didn't think this at the time. Instead, as he came up the driveway with his casual burden, the careful judiciousness of his narrow face beneath the hornrims and mephistophelian eyebrows seemed unforced and unphilosophical, as necessary as the face of the moon, the natural demeanor of any newspaperman.

As he came to the door, I smelled the pipesmoke in his grey worsteds, and tensed for the brush of his whiskers against my cheek. By his own admission, he was the only American in the world who wore a mustache. He said Groucho Marx was not an American, and what Clark Gable wore was not a mustache. Because of this bristle, a sort of black fender over his mouth, the men at the paper ribbed him and called him a Red, but he told me there weren't any Reds in our country and they knew it. I wasn't sure if I was supposed to believe him, because he also told me the sunset was made of angel's wings, and that something called sky-blue-pink was his favorite color. He said hiya, toots, to my mother as he walked in, and she said can the corn, Ernie, with an edge to her voice, and kept stirring the peas. That was as close as we got to a primal scene. But after supper, while my mother washed the dishes, he held me in his lap and read to me from Kipling's Just So Stories. He paused from time to time to call me his best beloved, and those sweet words, gravelling softly in his throat, seemed like the sort of thing any newspaperman might say, till one day I learned that they were only part of the story. Then he put me down, picked up his paper, and read it till bedtime, closely, like a novel, and there was nothing and no one to tell me that this was not all he'd ever wanted from the world. When that too became clear, it seemed, like everything else, to have everything in the world to do with me.

I was not the only child they had wished for. I had come with difficulty, after years of trying, but they had kept on trying after that, and lo and behold, eight trying years later, came a tiny girl. She was born with her lungs outside her back, so they looked like wings. She had already flown. After that, my mother began to suffer from dreams. She said bad birdies, and hung balls of suet soaked in rat poison from the branch of an apple tree. Many birds died. When I was nine she went away from our small town to a hospital in Philadelphia for a month. I don't remember who stayed with 
me, but when we finally brought my mother home, I sat beside her in the car telling her everything I'd done while she'd been gone, but she wouldn't listen, she looked out the car window away from me. She kept staring back in the direction of the hospital, as if she'd left something there. I believe she had, but she was brave and never mentioned it, and learned to get along quite normally without it. After that, she worked just like an ordinary housewife, but you could tell something was missing. My father was very kind to her, becoming even more of a newspaperman than he'd been before. And in the fall of that year, we left Pennsylvania.

His new job must have meant a great deal to my father, enough for him to move his family an intergalactic hundred miles to the northeast, away from its two centuries of nurturance among people, other PennsylvaniaGermans like ourselves, who didn't have to know us to know how our name was pronounced. Not the least astounding feature of my new home was a seismic shift in lineage from Hopf with a long Pennsylvania "o" to Hoff as in doff, which my father never tried to resist or correct. He accepted this debasement with a readiness that struck me as craven. But when we moved to New York, thirty miles north and west of the City, more than our name changed. Before that, I could still see him whole, but afterwards, as if by some trick of perception, he seemed to grow less and less visible until when I looked all I saw was the memory of having seen him. I think that in leaving the place where I was born, and the place where both he and my mother were born and all four of my grandparents and all of our ancestors as far back as anyone could remember, it instantly became possible for the person I would become to leave anything and go anywhere, even to the most unaccountable places, for the most unaccountable reasons, even, for example, to Laguna Beach, California, and it may have had the same effect on him. At any rate, what I remember from the first years of our life in New York is mostly the anxiety of his comings and goings, appearances and disappearances at odd and unpredictable times, his bursting in through the garage door at two in the morning or standing up in the middle of dinner, in mid-sentence, in mid-mouthful, to wipe his hands on the dish-towel looped through the refrigerator handle and be off to the train station with a morose peck on the cheek of my unsuspecting mother, whose mood at this time was one of permanent alarm.

He was now with a much bigger paper, in a much bigger city, and he worked all kinds of shifts, plus holidays and overtime, whatever they asked 
for, whenever the black phone next to the dinner table rang like a timer and my mother jumped two inches as if she'd been stung. He no longer read to me, although I didn't tell him that at the age of ten I would still have welcomed it. He lived more and more behind his newspaper, of which there was more and more to live behind, and when he worked nights I knew him only as a presence that cast an absence over the house, causing my mother to leap in panic if I so much as laughed or raised my voice. She took to doing crewel-work in a wing chair, easing the needle carefully into the stitch as if she were afraid the very cloth would scream out loud. Her samplers and floral essays, all pre-printed, went into a drawer. She finished an entire German alphabet after Kennedy was shot, when my father stayed at the paper for five days.

On the sixth day, as he walked in the door, his face looked heavier beneath the heavy glasses. After supper, I was reading to myself on the sofa in the living room when I heard a sound from the kitchen like a kitten mewing. I hid behind the kitchen door and peeked out. I saw my mother crying into her hands and saying, I want to go back. My father looked sadly at her across the table, which seemed very wide, and said, you can't go back. I want to go back, I want to go back, she whimpered, and he frowned and whispered sternly, Jean! She jerked her head and hushed as if she'd been struck. I stepped into the room. They both stared at me as if neither could remember who I was. I said let her go crazy again if that's what she wants, and my father slapped me as my mother looked away from us both with an ironic smile.

We never looked back, and although it would be incorrect to say I forgot the whole thing, even then I understood that I had simply pressed the wrong button in a highly complex machine I had once known how to operate. He'd hit me hard enough to make me bite my tongue, and the blood in my mouth had the flavor of another time, in which other possibilities had existed, while I had not. It tasted at once familiar and impossibly strange. I had a sudden blinding sense of my own father's failure - to do what, it would have cracked my universe to imagine, until now, when it no longer matters. I have struck my own son when all I wanted was for him to leave my aching heart alone.

Most of what I know about my father, my mother told me. His own forthrightness masked a profound and frustrated preference for incommunication. He never talked about his work except in the baldest terms: I 
gathered that he corrected newspaper stories for grammar and punctuation and obvious matters of liability, and that he wrote headlines. Yet I also knew, or was taught to believe by my mother, that he was not only perfect for his job, but for his august employer. And in spite of whatever doubts might lead him at moments to raise his hand against his only child, I believe it meant a very great deal indeed to him to be national copy editor for The New York Times of Times Square, Manhattan, The World.

I'm a children's librarian myself, and as Victoria reminds me over and over, that's okay, but the public library of Laguna Beach, California, is not the Library of Congress, and when I was young I thought of the Times that way. My mother revered the Times and my father equally, even as she hated the one for taking the other away from her, and through her eyes I learned to see that newspaper as an Olympian institution whose rationalist ideals my father served and humbly upheld. Long before I cared one jot about the news, it was in those doric pages, with their slender columns of dark lettering, that I read the important truth that important things don't happen very often. This belief was a sturdy bone in my father's character. And mind you, these were years of almost continuous upheaval, scarred more and more since that week in late November of ' 63 by periods in which my father was simply too busy to ride the train home from one deadline to another, years in which great men were murdered, cities burned, bombers darkened the skies over tiny nations, and all of this was told in those studious, well-mannered headlines of almost pathological laconism, more than a few of which my father must have written, that seemed to suggest that none of it really mattered.

Only once did we visit his newsroom. I remember strolling, between my father and mother, my father's hand strong, my mother's quivering, out of a Boschian city into a dingy elevator and from there into a fluorescent-lighted warehouse of desks and partitions and trashcans spilling over with crumpled-up sheets of typing paper, past lipsticked receptionists and lounging or scurrying newspaper denizens, every one of whom went out of his or her way to say hello, Ernest, to this man who would not eat a piece of bread I had touched with my own fingers and could not, as a matter of principle, smile at a camera. This is true. The few times my mother and father and I lined up on the back porch of our suburban home to have our picture taken by a visiting relative, my father would scowl so hard it made the rest of us laugh. Come on, Ernie, smile, the aunt would timidly 
suggest, her deference magnified by the squint of her entire face into the Instamatic. He'd answer, why should I smile, I'm not happy. Just smile for the camera, we'd plead, but he'd get huffy, only half in fun, and go nossir, I told you, now, I'm not smiling. He'd say what do you take me for, a hypocrite?

At the Times, I noticed, they didn't make that mistake. My father picked up the tickets for our show (careful to make it seem like his only reason for stopping at the newsroom), then guided us unsmilingly toward Lincoln Center, past the smoking carts of chestnut vendors, a soap-box apocalyptician shouting down a crowd in the glare of a streetlight, a covey of baldheaded, draperied Hare Krishna people dinging their finger cymbals in the rose-colored glow of a barricaded knife-and-gun shop window, and his familiarity with these obscure phenomena was matter of wonder to me far greater than all of the City itself, which his presence alone rendered not only possible, but plausible, as it has never felt since. For my mother, it must have been otherwise. What marquees blazed luridly in her mind I do not know except that they were not the ones my father marched us under, and the peep-show placards she saw bespoke a girl who was not the one in the shadows with a burly mustache, hitching her tight pants down with a crooked thumb. This was my mother's first trip to New York City, and her last. She had undertaken it against her own strong revulsion, as an act of subjection to my father's wishes. Ordinarily she could barely bring herself to voyage as far as the corner grocery store. But she trusted my father not to insist on something he wanted only for himself, so when he'd kept on insisting, she had cried the tears of the defeated, and finally said yes.

And for a while after that she seemed to be better. It was as if the trip to New York City had broken her shell, as my father had hoped, and she tried to emerge from the emptiness inside. She soon volunteered at the local library, reading stories to children every Saturday morning. She always chose books in which animals talked like people, and went about their serious lives with a lucid and startling whimsy. There was a long black bookshelf in our TV room that was stuffed with children's books, many of them ancient. Many had been read to me when I was small, but some had not, having come down by mysterious paths from earlier times. They were not as colorful as the newer books, their spines might be split, and often on the flypaper would be an inscription in an antique hand to some Teddy or Joey that we'd never heard of, love Grandpa, for some long-ago Christmas 
or birthday. I used to frown, thinking that that child must have died, or both his parents had been killed in a plane crash and he was institutionalized, or their cozy home had burned to the ground, taking all souls with it, leaving only this book, dampened with hose-water, which had caused Grandpa's inscription to smear and run.

Those books were orphans, and for some reason I wasn't conscious of, had frightened me. But my mother now spent hours beside that bookcase, combing through them, looking for something unusual to read at the library. One day, while I was watching television, she sat beside me opening books that hadn't been opened in many years, and it was like opening graves. Each book gave off a different dusty smell. She read them slowly, as slowly as a child would read. Then she turned the last page of the book that was open on her lap-a book of simple love poetry, not really for children, but neither what any literate adult would buy - and something fell out. It was a piece of flowered note-paper, folded over, jaundiced with age like the book itself and inscribed in a looping hand in fountain pen that had long since bled penumbrally into the fibers. My mother seemed to become very still as she read it.

She noticed me looking at her. The television grew louder. She handed the note to me, and I also read it. It said: Ernie,

The sky is blue, the sun does sink, The clouds are colored sky-blue-pink, And now with all my heart I think My love for you will never shrink.

It was signed at the bottom with a woman's name. Matter-of-factly, I said, that's his favorite color. My mother looked at me with hollow eyes and said, that is not my name. I said of course that is not your name, your name is Jean. She said I always wondered where he got that color. It's his favorite color, she said, it always was. Then she folded the note, put it back in the little old book, closed the book, and buried it again between two other books on the black shelf.

She soon stopped reading to the kids at the library, she didn't say why. She crawled back into her own quiet world, which seemed to stun her with its din. She had plenty of time for it, since those were newsworthy days, and my father was now a newsman of some importance. But it no longer 
bothered me that he was gone so much. I was intensely proud of him, and of the work he did. I leaned toward him, and away from my mother's halfspilled vials of medication, her silent roaming from one clean room to another, the children's books which were all she read any more, but only to herself. As fär as I know, she never mentioned the note, and I kept her secret, even on the morning one year later when my mother hung herself from a basement rafter.

It was an August morning, soft and lovely, with dew on the grass beneath our apple trees, and due to intensive coverage of special events, my father had been in the City for three or four days. Our basement had a low ceiling, and when I found her, my mother seemed to be standing on the floor. I called her, but she made no answer. She was looking away from me with her head cocked, as if searching for someone.

My father came home immediately. He was carrying the newspaper folded under his arm. The headline, which he had composed, and which I would come to think of as his greatest work, was a fragment of Egyptian monumentality. MEN WALK ON MOON, was all it said, and beneath that, in slightly smaller italic capitals, "A Powdery Surface Is Closely Explored." My father hugged me awkwardly-there was the smell of pipe-smoke I hadn't noticed in years, the scrape of whiskers. He told me I couldn't have known, and not until that very moment did it occur to me that, of course, I should have known all along.

I told all this to Rusty many times. It was important for me, with my own son, to tell him everything, to hold nothing back, but the ironic thing is that it made no difference. He still couldn't see me. Victoria says it's not ironic in the least. She says the act of revelation is nothing but one more mask, the most frightening of all. Maybe children are still aware of this, which we grownups have forgotten, or choose to ignore. Maybe that's why children listen to every story, even the most innocent, on the edge of their seats, with their eyes wide open and their mouths agape, as if it were a tale of horror. I notice this every time I give my tours of the library to the pre-schoolers and the kindergartners and the first-graders (not so much the first-graders) and then sit them down in a circle in my corner of the building, the corner where the books are tall and thin, or wide and thin, and full of pictures, and there are pieces of choo-choo train lying on the rug, derailed, and I read to them. I hold the book open to the ring of listeners 
who carefully watch each slowly turning page, not as we grownups would, with amusement or impatience, but with awe, and with a deep uncertainty. They know it's a trick but they don't know how it's done, and they're never sure that it won't blow up in their faces.

And sometimes in the last few months since Rusty ran off, or the last six weeks, since I went back to work from my extended leave, I've wished that it would: would just blow up in their faces. I'd turn the very last page and they'd all be gone, wasted, blasted, vaporized, and I'd be left sitting there alone in a smoking silence, a few small scratches on my face, my hair disheveled, closing the book and sliding it back on the shelf. I've had that dream several times, and sometimes in the dream it's my mother reading to me, only I'm old, as old as I am right now, or even older, and my terror mounts as she reads me some charming book about animals dressed as people, living their complex lives in buildings and towns, driving their cars and going to work each day, and someone gets sick or lost, or somebody dies, but still she keeps smiling and turning the pages slowly and I knowknow with a cold, dead certainty - that at the very last page I'm going to be annihilated. And then I wake up.

I try to go back to sleep, but if I can't, even in the wee hours (all of my hours seem like wee hours nowadays), I call Victoria. She says that's what she's for. I love to hear her picking up her special bedside phone with the unlisted number, and mumbling into it, her tongue and lips muzzy with warm sleep, her brain still under the blankets but ready and willing, never impatient, never irascible-willing. Professional. Sometimes, I don't know why, it depresses me. Ruth says why don't I just go live with her, but you don't live with someone professionally. The profession is marriage, and I'm still married to Ruth, though Ruth won't see me and doesn't like to talk to me and actually wanted to divorce me outright, but Victoria talked her out of it.

As for Ruth, she sleeps alone in our old water-bed, under the utterly un-Afghan-looking afghan she stitched herself when we'd first bought the thing. It's the same bed where Rusty slept for those five nights six months ago - is it just six months? - with his girlfriend, Shyla, while Ruth and I were in Maui. It was our first vacation alone in seventeen years, and maybe our last. It had gone so-so. I find it depressing to be surrounded by so much that is forbidden, when it's wearing so little. As for the rest, Ruth burns, and I don't swim. She likes to "see things," but lately museums only 
remind me of work. About the only thing we'd done together was worry about Rusty. We'd called him at home every night, of course, and he'd said things were fine. Come to find out that things were fine, all right, as fine as things had ever been in his short, oblivious life, so fine, in fact, that he forgot the eyes of neighbors.

Ruth and I had hardly gotten home, we were climbing out of the car still wearing our airport leis, when my elderly neighbor Sam Larson hollered howdy through his hedge of bamboo. Actually, what he said was aloha, Mr. and Mrs. Hopf, and he pronounced it "Hoff" like everybody else. I don't know why, but for the first time in twenty-five years, this bothered me. I said dammit, Sam, its Hopf, like hope with an 'f.' He scratched his head. He said Fope? How do you get Fope? I said forget it, Sam, aloha yourself, and after the usual pleasantries he allowed that children were undoubtedly a trial and a blessing. He said it was a blessing to be tried and we were undoubtedly blessed more than most, certainly more than he and the missus had ever been tried-blessed - with any of their three children, God bless 'em. He said a lot more, but our genuine orchid leis turned brown in the sun before we could drag it out of him that Rusty and a tall blonde girl had been observed, as he put it, entering the house each day at suppertime with a bag of groceries and leaving hand in hand the next morning, after breakfast. When she heard this, Ruth started to tremble, and set down her suitcase. I picked it up, and carried both suitcases in. I felt like a bellboy entering someone's hotel room.

Ruth cried when we sat Rusty down and (as they say) confronted him. $\mathrm{He}$ admitted bravely that he and Shyla had slept together, in fact had slept in our bed. When I asked him why he hadn't slept in his own bed, he looked indignant, and said Dad, it's built for an eight-year-old. While my wife cried some more, I thought of that children's book in which a man discovers his own head in a shop window. The man had been searching for his head for a long time. I heard Ruth say this is the worst thing that has ever happened to us. I said can it, Ruth. She said can it yourself, you rigid Pennsylvania-Dutchman. She had never called me that before. Rusty protested, but Ruth held up her hand and demanded, what do you intend to do if Shyla gets pregnant? She said your father and I do not believe in abortion. Actually, I said, maybe sometimes abortion - but Rusty cut me off. He said she won't get pregnant. Ha, went Ruth, that's seventeen talking. No method of birth control is foolproof. Rusty met her eyes squarely and 
said our method was foolproof, do you want to hear about it? Ruth cried out like she had been stabbed in the belly and covered her ears, while I sat there getting a hard-on. I said what kind of a name is Shyla, anyway?

I think it was middle Eastern-Lebanese or something-and her skin was a warm olive-brown even in winter, but in every other way she was pure California. She was tassled with a straight sweep of cornsilk yellow, and when she climbed out of the waves with the Pacific Ocean dripping between her thighs, that hair fell lower in the back than the bottom of her oxygen tanks. I imagined it getting tangled on some apparatus. But the apparatus seemed as much a part of her as her own lungs, she carried it lightly even when she was fully emerged from the water. Rusty had met her in the scuba club at the high school. He'd never seemed like the type for football or wrestling - or girls, either, for that matter, so it caught me by surprise when he calmly brought home this work of nature one day, like a perfect shell he had found along the beach.

The house was full of them - shells, I mean, and driftwood, sand dollars, barnacled stones, piles of crab carapaces, the corkscrewed casings of vanished tubeworms, all of it Rusty's. It does something to a kid to grow up next to an ocean. He sees that nothingness is not really so empty; he reaches into it. Myself, I can take the beach or leave it -isn't it strange how whatever unheard-of place where you pause in life long enough to raise children becomes their fatherland? - but to Rusty, it's home. Right from the beginning, when he wasn't skate-boarding, that's where you'd find him. In fact, right after he was born, in his very first week, I'd bundled him up in my arms and carried him down to the Main Beach in the twilight. Ruth told me not to, but I'd scoffed at her. The wind blew up and licked at his cheeks. He cooed and blinked his eyes. Pink streaks of cloud stood out brightly against the still-blue sky over the ocean, like cockatoo feathers pasted to a window. I held Rusty up so the sunset made a peach of his blanketed face, and I said look, that's what makes people think there is a heaven.

You can say things like that to a baby and not feel crazy. But with Rusty, perhaps because Ruth was so utterly uninterested, I could never stop, even when he wasn't a baby anymore. And there was craziness, too. When my son was small, it was easy to be angry with him, his demands were so peremptory, so unyielding, so ruthless, continuous, and undefined. Yet it was also so difficult to be angry with him that when I was, I had to ques- 
tion my own decency, my goodness, my very sanity. I dipped occasionally but regularly into ennui and self-disgust; I was shaken to think that even my love for my child was like everything else, a mixed-up thing - that it wore, so to speak, my body, and was imperfect. I learned that a father was nothing but a man with a child, and there was some forgiveness in that; some humility, too. Ruth rarely slept well in those days. She got all twisted up inside, berating me for not being home enough and not helping out enough at home when I was, though I helped out a lot, it seemed to me-more than most fathers. What really upset her, I think, was simpler than that: She thought I was not as miserable as she was. I think she was wrong, though I could never say it.

She hadn't wanted this child. I don't mean to say that Rusty was an accident. We'd tried, and succeeded, and thrilled to the triplet-tap of the baby's heartbeat beside the great swishing river of Ruth's aorta. But as time grew into its fullness, she turned away from the sudden insistent aliveness inside of her, shifting her body this way and that to get her guts out from under those trampling feet, with all their relentless burden of care and cost and pain. She began to cry a lot, at home, alone, and one day she looked at me with eyes emptied of tears, and said that she hoped the child would be born dead. I turned from her. It is one of my great regrets that I failed to understand the depth of horror that was speaking through her that day, but all I could understand was that along with a child I had conceived a lifetime of remorse and the knowledge of failure. I saw, like a prophecy, a long train of years filled with deceit and longing. I told Ruth to shut up, and never to speak to me like that again.

She was a woman who swayed at the touch of cold winds from deep inside, and maybe I was one of them. But after that, she shivered silently. That was the start of our near-complete disparity of instinct and inclination, which we gingerly embraced as a sign of our evolvedness. Ruth knew a lot about evolution. At Northwestern University, where my father had sent me with enormous relief after Mimi disappeared, Ruth was a reasonably pretty anthro major with a minor in psychology who'd never had the slightest intention of becoming either an anthropologist or whatever it is a psychology minor becomes. The very question, in fact, of what to "be" was a primitive wind against which she steeled herself, and at least in psychology she found the words with which to make anyone's torments, including her own, meaningless. What she found in anthropology I was 
never sure-a love of the higher centers, the proper tool, the use of language as preemptive weapon. But the winds were still there, and when she got that hunted look in her eyes, I knew she was dangerous. For this reason, I never told her more about Mimi than she needed to know.

Sometimes it seemed that the most permanent effect on Ruth of higher education was a more exquisitely complex feeling of guilt at the things she continued to enjoy the most, such as knitting or flower arranging or reading science fiction novels. Even so, when Rusty was six months old, she took a part-time job at a flower shop just to get out of the house, guilt be damned, leaving me at home with him for a few hours before the library opened, when I would take him to Mrs. Larson's, who had agreed to babysit. We went on this way for several years, while Rusty grew into a moody, brilliant child who made of those years the best and the worst of my life. He never stopped blaming me for being there instead of his mother, as if, each morning, I had killed her and stuffed her in the closet before he woke up. I'd explain to him that mommy was at work, that the flowers needed to be arranged very early, when a baker bakes bread, so the people could come in and buy them before they died, but he brushed aside all explanations with imperious sorrow. My inability to console him wounded me. I was discouraged to realize that it would probably never matter how much he meant to me. He would want something else, and in the end would have to find his own solace.

I used to tell him bedtime stories about an armored vehicle that had wings like an angel and flew around picking up souls like bags of money to take them to another time and place. These stories caused him to suck more sternly on his pacifier, and I only wish I'd really had a Brinks car of the soul to whisk him untouched through his vulnerable years. Instead, I had a dream of my own, which ran right over him. I saw myself in my middle twenties living in this faraway place with a wife and child, working as a children's librarian, and sometimes it all seemed so rash and inexplicable, so far from poetry, that I felt it could not go on for very much longer, and yet it did. Visions would come upon me periodically, then depart, leaving me helpless. I wasn't happy in the children's corner. I still felt at that time that I'd been made for something bigger, and mostly my vision was of a strong man in charge of his thought, charging down the years toward some sort of triumph. So I applied and was accepted at UCLA in the graduate program in philosophy. I cut back to less than half-time at the library; Ruth 
hustled her anthropology degree to the flower shop full-time; and at the age of only three and a half, Rusty went into formal, brand-name day-care five days a week, for nine hours a day.

I had a boundless energy born of desperation. I immersed myself in existentialism and phenomenology. I set my alarm for 5 o'clock in the morning to exercise before my fifty-mile drive to lectures, and still my grades were perfect. Even Ruth seemed happy for a while with her work, but there was an undercurrent of anger and strain. The dislocations I felt on Rusty's behalf, those I imagined he was simply too young to give a name to, hurt me badly. As winter turned to spring, I seemed to be working myself farther and farther into a sadness that had no name, a flickering desolation that sat like a fire on my heart.

One Saturday morning in April, I got up and exercised, then I read for a while to Rusty. After that, I retreated to our bedroom to study. I was reading Merleau-Ponty, where he says that "two things are certain about freedom: that we are never determined, and yet that we never change," when Ruth came in. She had a little outfit she was sewing for Rusty. She sat heavily on the edge of the sloshing bed, with its absurd comforter of uncomfortably primary industrial-strength dyes, and said you love it when she keeps herself busy with her stupid little hobbies. Ruth was large in the bone but ungenerous in the flesh, a physical divergence within herself that only became more pronounced with the passage of time. I had a term paper to write, but she had a skullish quality about the cheeks this morning that would not be denied. I said your hobbies aren't stupid. She said just little? I waited in silence. Then she said, you've always been too good for us, haven't you?

I knew it was over, but somehow all I felt was an overwhelming desire to finish this chapter in The Primacy of Perception, immediately. I said what? She said what is $m y$ life for? She seemed to be baffled by some stinging pain, shaking her head like a child who has been punished for nothing. It isn't easy to form an accurate idea of the forces at work inside another human being. I suspected that she didn't really care what her life was for, that for her these words were like the sounds of animals, no less familiar, no less puzzling, but ultimately no more interesting either, and that she would soon go back to ignoring them as an animal who had better things to do. I may have been wrong, because when I answered her to the effect that I hadn't a clue, she violently wrestled Merleau-Ponty from my hands and 
heaved him across the room, where he shattered a mirror. Hey, watch it, I said, that's a library book.

You don't care about me, you don't care about Rusty, she shouted, this is all just selfishness! She enunciated the word so vehemently, she doused me with spit. I took off my glasses and wiped them on my shirt, considering the possibility that she might be right. I held up my glasses and squinted through them, away from her. Slowly and quietly I said, do you want me to quit? She said oh no you don't, then she burst into bitter tears. I won't have you looking after my child, she sobbed, as Rusty walked in and stepped right up to her. He stood with the almost military bearing he had when he was four, and demanded to know why his mother was angry. Because I'm not good enough for your father, she cried out to him, and I never have been. Rusty paused, as though he too were considering the likelihood of this. Then in a voice of soothing reason he said, Daddy's good to you some times. But this only made his mother sob harder, and he looked at me reproachfully.

So I quit. I gave up the whole idea of philosophy, and Ruth told me what a relief it was to her. This made me glad. I was happy to please her. I packed up my copious notes on Merleau-Ponty and withdrew from the UCLA Department of Philosophy, saying goodbye to the young and eager faces there, too young, too eager, whose dreams were Rusty's dreams, untroubled by angels, and returned to the children's library full-time. I settled back into the routine of work and child-care with a certain relief mingled with terror. Some days were all right, but on others I was profoundly dejected about the course of my entire life and felt like bursting into tears in public, in front of strangers. Depending on which kind of day it was, I was gentle and patient with Rusty or nasty and explosive and irrational and unpredictable. It must have been hard for him to live with such a capricious and contentious father, but he was forgiving, and I tried to be, too.

Around this time, my own father made his first and only visit to our house in Laguna Beach. He had recently retired from the Times and was finally ready to do some travelling of his own. Since college, I had seen him only twice, when I had been willing or able to make the trip back east, and the ease with which I had grown accustomed to going two or three years without seeing the face of the man who had given me life would have shattered 
me if I'd taken the time to think about it. I had only to project into the future the very naturalness of this abandonment - there's no other wordand imagine a time when Rusty would think of $m e$ as someone he used to know, to feel the collapse of all that I held as true. But there was a sense, with my own father, in which I had more or less consciously decided that I'd had enough of him. I think he knew this, and accepted it as well within the bounds of normal relationships, compatible even with what others might call love (we called it nothing) as that feeling is understood between fathers and sons.

At any rate, when he visited us that year when Rusty turned five, he did not allow any sense of what had come between us to temper the severity, among other oddnesses, that age had brought him. The jumbo jet at LAX disgorged a shambling and disoriented man in an orange and green porkpie hat and a snow-white goatee trimmed too short to cover the florid pink of his jowls. There were still the formidably tectonic black hornrims, which now only accentuated the weakness of the whiskers framing a mouth that seemed to have grown irreconcilably dour. There was a stoicism to its dourness that I remember as terrifically impressive. But when he approached, and I shifted Rusty's weight to my left arm, he shook my hand with an affirming warmth, then slipped his palms around the boy's middle and broke into a kind of rictus grin. So this is the little Hopf, he said, and he surprised me by pronouncing it like a Pennsylvania-Dutchman-like hope with an "f." He's a Hoff, Dad, I said wryly, just like you. My father cocked an acerbic eyebrow at me and said, I thought you would've moved beyond all that. He said what the hell else is a West Coast for?

He greeted Ruth, who didn't hold it against him that this was the first time he'd ever seen his grandchild. Ruth had always admired and respected my father. He seemed to have this effect on younger women, even Mimi, but with Ruth he had returned the feeling unreservedly. It had crossed my mind from time to time that he might even be one of the reasons, if reasons were necessary, why she'd married me. Certainly her letters to him were longer than mine, and his to her (or the paragraphs he addressed to her in his letters) were couched in the voice of a man I'd never known. This caused me no jealousy - he'd been denied a daughter-and injected at first a certain non-specific energy into our marriage, like the vague suggestion of incest in a novel.

My father took Rusty for long, lopsided walks through the neighbor- 
hood, and when they got back, as often as not, he would read to the child on his knee. But as he read, in that gravelly, tired voice I remembered so well, he upset me by providing Rusty with a running critique of the literary qualities of whatever Golden Book or First Reader the boy had handed him. If the story got too cute, he'd cry isn't that wonderful! with a devastating sarcasm that winged right over the frowning child's head. At the end, he would close the book with some phrase of dismissal-God, what a lot of meretricious nonsense! - aimed more, I knew, at my choice of profession than it was at his young listener. In private, I said to my wife that I didn't think it normal for a man of his years to talk that way to a five-year-old. Ruth defended him angrily, saying that he was only being honest. I said I had no use for that kind of honesty. She said then I'd have no use for what he thought about my quitting the graduate program in philosophy. I said that I thought my quitting had been her idea. She said you'd like to believe that, wouldn't you, and sure enough, my father laughed scathingly at me about it. He said that when I, Ernie Jr., was a child, he'd never given a thought to my quality of life, and he yanked that phrase around with manly contempt. But in private my wife said right, and look at you now. She said it's no accident you live in Laguna Beach.

It was no accident, in more ways than one. I'd first heard that nameSpanish, a pond or pool, from the Latin for "gap" - in one of my mother's stories about my father. It came out of a time that lapped like waves against the shore of my existence - the last few months before he'd met my mother and rather abruptly married her-and cast a light on him so much at variance with the light he'd apparently chosen to cast on himself that the story had stuck inside me like a fish-hook. I'd never dared to mention it to my father, but on the day before he left Laguna Beach for the second and last time, I drove him down to Heisler Park and sat with him alone for a while.

We strolled past the lawn bowlers to a sandstone bluff overlooking a tidepool. The sun was fat and orange over the ocean, making with its reflection a blinding upside-down exclamation point that forced us to turn more obliquely toward each other than we may have been comfortable with. He wore the motley porkpie, despite the heat. I said you've been here before. He said so you know about that. Lately his voice could pass, with a wink of inflection, from gravel to growl. He lit his pipe, took a few initiatory puffs, and shut his mouth on the stem like a steel clamp. I felt the memory on my cheek of the one and only time he'd ever hit me, as I said, 
did you think it was pure coincidence that I moved here? He shook his head. I said what was the town like back in ' 47 ?

He looked south along the beach. The bounce of basketballs and the thwock of volleyballs arose from among the noise of late-evening bathers that from this distance resembled the animal sounds of a rookery. He puffed on his pipe. It was different, was all he said. I said how long did you stay? He said long enough to look at the water, and I thought he looked a little sheepishly away from me. I pictured him sitting on a big chrome bumper for half an hour with his elbows on his knees, staring into the irrelevant blue breakers - and above the breakers, like a wail of glass, the sunset-blue Pacific Ocean sky, pasted with clouds the color of angels' wings - then simply getting back in the DeSoto and driving it home, to Pennsylvania. I said why did you come?

$\mathrm{He}$ peered at me as if I were possibly dim-witted, and said it was the end of the road. I said no, I don't mean here, I mean why did you come? He said no reason. There had to be a reason, I pleasantly insisted, you'd quit your job and everything, according to Mom. I mentally shielded myself before I added, that wasn't like you. He looked at me swiftly, cuttingly, and said, you know what I'm like? Then the look was gone, and the shrug of his shoulders signified only boredom - he seemed to get bored very easily nowadays, and seldom troubled to conceal that fact from anyone-as he almost inaudibly said, so tell me the reason. I flushed, and said a lousy boss, a weary mind, a broken heart. He said take your pick.

He had put on dark glasses on account of the sun, and when I didn't say anything he looked out over the ocean for a while. I felt like he'd pushed me right off the edge of the bluff. Then he picked me up and dusted me off and set me back on my feet like he always could, simply by asking, without so much as a smirk, why did I leave? I stilled my heart and answered, you tell me. He said there's a woman buried in Pennsylvania who is your mother, and you want your father to tell you she isn't the only woman I ever loved? I felt the hairs up and down my arms lift and prickle, though the breeze was warm. He sucked deeply on his pipe, making the juices pop. He inhaled, and blew out a cloud of smoke. He said what's the difference? Just beyond the tidepool the surf pounded over and over like a giant bellows. We both looked straight ahead, into the sun. I said it makes a difference. He said you'd be crazy to believe that.

The next time I saw my father, he was dying in a coronary care unit in 
New York City. It was nine months later. I'd flown back alone after a doctor's phone call. The doctor had said that I "might want" to come. My father seemed glad to see me, but uncertain who I was. Under oxygen and IV tubes and a panoply of monitors replete with flashing lights, he seemed larger than I remembered. He seemed huge, wet, stunned, like a beached whale. After a bit, he said you seem friendly, sir, is there something I can do for you? I said Dad, this is Ernie. I felt like I was still on the telephone. He said Ernie, how are you? I'm fine, I said, how are you? He said I'm tired, and a little worried. He said some strangers visited me last night; they frightened me, but didn't hurt me. I said nobody's going to hurt you. He said don't be silly, Ernie, they all do. Then he took my hand. He asked me where I would teach philosophy when I got my doctorate. I said don't you remember, I quit that a year ago. (It was longer than that.) He said it's not too late. I said not for you, either. He said yes, I think it is. He grew tense and puzzled, and gripped me by the arm. His hand felt damp, even through the cloth of my shirt. Doctor, he whispered furtively, check me over. Check my mind and my blood pressure, my heart, my passageways. $\mathrm{He}$ looked fearfully out of the corners of his eyes toward the nurses' station, then fell back exhausted. Some of the monitors began to beep, but it must have been something routine, because they stopped, and no nurses came in. To change the subject, I asked if anyone else had been in to see him. He said sure, Mimi was here, I guess you missed her. He said remember Mimi? I said I remember Mimi, Dad, and she wasn't here, and I've always missed her. Then I started to cry, and said, I miss her bad. He reached up and laid his wet hand on my wet face. With an indescribably gentle sweetness, he said, I know that, son, and I am sorry.

It's hard to keep your history in the past. On the same morning of my seventeenth year, the Eagle had landed and my mother was dead, and these two events became entwined for me in a way I have never entirely been able to unravel. Somehow my father made the headline for them both, but only one of them was in the newspaper, and that was by far the less significant, which was as it should be. When I was at Northwestern, after Mimi was a memory and before meeting Ruth and becoming a librarian, I studied history when I wasn't studying literature. I observed that history's cusps are generally worn to an Appalachian smoothness, so that from the top of one the summits of many others before and behind recede mathematically into 
the distance like a groundswell. But now and then in the ocean of time a peak rises up beneath our feet from which neither the future nor the past can begin to be glimpsed, because they are too far beneath us. We lower our eyes and discover ... a powdery surface, which, being ants at heart, we explore closely, and attempt to describe in words of unextravagant precision that will not make too much or too little of our own insignificance. Deep in his Pennsylvania-German heart, my father seemed to cherish the Timesian belief that as events swelled in magnitude, the proper headline ought to shrink and get out of the way. MEN WALK ON MOON: That was headline enough, really, for what they had done. It was another German, Wittgenstein, who wrote that where we cannot speak we must pass over in silence, a formula of deceptive and terrible simplicity that would render as an expanse of pure and empty whiteness the only possible Page One for the day when a boy's mother hangs herself inefficiently with a long rope from a low rafter. When the Eagle lands on the dust of our own hearts, the only headline is silence.

So we never talked about my mother's death. Ruth diagnosed in this a dangerous pregnancy, and in her science, words were like the abortionist's vacuum, emptying reality, for those who wished, of its separate life. My father and I never saw it quite that way. The thing had happened, whether we spoke of it or not, and before very long we had other things to talk about. We were headed toward a time when life turned on its siren and went screaming through several red lights, and my father would not like the noise. The siren had a name. Her name was Mimi. I picture a girl-a very young woman, hardly more than a child - with hard, undaunted eyes and a childlike nose above a mouth twisted on the right into the makings of a smile. The first time I saw her she was walking on thin ice toward a bonfire.

The fire was near the outlet of a pond, and most of the skaters took a short-cut to the bank and walked along the bank in the snow to the fire, where there were benches. But this girl walked across the frozen pond the long way and didn't stop when the ice began to creak and groan beneath her where the water gathered itself into a current, but stepped lightly and confidently, without breaking through, to come up directly in front of the huge fire, opposite the benches, where I sat, watching her through the flames. Over her shoulders, the long trailing blades of her figure skates, held by the laces, stuck up in a V. They must have been new, the way they 
caught the light of the fire and flung it around. Her hair was draped down the front of her shoulders in two thick ropes - it looked chestnut-brown in the firelight, though it was black - and drawn apart so tightly down the middle of her head that the part stood out as straight as an incision, pale as a scar. She wore knee-length leather moccasins over her jeans, and her jeans were low on the hip, in the style of those days, and they buttoned, and the highest button had been left undone. Her face was virginal and full and she had a way of looking at you by inclining her head and sighting upwards through her eyelashes. The eyes were black and imperious as a falcon's and I saw her face as a kind of memory, not an altogether happy one, but one that stirred in me feelings of longing and sadness that shot beyond desire to the knowledge of possession and beyond that straight to the knowledge, certain and clear, that she would leave me. As she stepped to the shore that night from the crumbling ice, it felt more as if something were ending in my life than like something beginning. She felt it too, and said hello as if she were saying goodbye.

Her father had left when she was very young, and her mother moved around. We were both seniors, but Mimi was new at the school. She rounded the fire and asked - demanded, really - that I help lace her skates, which were stiff from the box. Unlike me, she was a wonderful skater, and there were some other good skaters on the pond that night, but she didn't seem to mind staying with me and trying to show me how to move my feet. She had this way of talking, at once racy and infantile, like a child mimicking indiscreet parents, that immediately hooked me. As she watched me skate, she shook her head sadly and said no no no, this is bad, your bladework sucks. Then she held out her hands like a dancing instructor and said, come to Mimi. There was such a peremptory tone to the suggestion that I came without thinking, and she skated along with me toward the bonfire, holding my hands, saying left, right, cross over, and so forth, and I was doing pretty well, until suddenly the ice did break, and we landed on top of each other in a foot and a half of black, bone-chilling water. That alone was reason enough to meet again.

We became inseparable. I had never had a girlfriend before, and now I was spending many weekday afternoons and most of my weekends with Mimi, usually at her house. When her mother was home, which was seldom, she hardly cared what went on in Mimi's room or downstairs in front of the TV set. It wasn't much-a lot of kissing and tongue-play, some 
cloth-tit, as I'd heard boys call it, a little dry-hump-but it was existence on a whole new plane for me, and this only five months after my mother had died. It came as a relief, because although I'd never mentioned it to anyone, and being rather solitary really had no one to mention it to, my absense of emotion one way or the other about either her dying or the manner of it had shocked me. For my sake, my father carried no overtime any more, though he made no more effort than he ever had to do things with me. I understood that to have done so would have given him a painful sense of using the death. So I think he was also relieved, initially, when I began finding preoccupation, as a young man should, in the opposite sex. But there was a point where he clearly felt called to intervene.

I'm sure he'd rather have let things take their course, and he didn't say anything until a night of falling snow when a storm surprised him without a car at the train station. Meanwhile I was shivering at the wheel of our old Corvair, hunched forward to peer over the headlights into the chaos of onrushing flakes, following my twisted prick, and not to the train station. The road was deserted where it went through a woods. Suddenly I picked out a ghostly figure striding toward me out of the blizzard in a jacket and tie, his hands in his pockets, his pants billowing from his long steps, and a newspaper naturally and necessarily under his arm, his cross and his shield. He was in another world. Flashing upon him like that, transfixed in the sweep of the low beams like a deer or a badger, sent it through me with a jolt of awareness that my father was old. Forgetting everything, I heeled the car around on the drifting two-lane and pulled up beside him. The cardoor made a snow-muffled sound, and he spoke my name, and even before the snowflakes had started to melt with the smell of wool into the grey tweed of his shoulders I sensed his anger, and understood that I had made a mistake I had never had the power to make before.

Where was I going, he demanded, in his car, in this weather, at such an hour, and without a coat on to boot? I felt that he wanted to know all this without really knowing, but there was more. I will ask you a question, he said, and answer me honestly. Do you and this Mimi "make out" when you're together? He said the phrase the way you say something in quotation marks, and for a moment the only sound was the heater blowing and the snowy wipers making their pillow-slapping sound. It was overwhelming to be in the driver's seat with my father sitting next to me like a child, asking childish questions. Finally, too astonished for denials, I said of 
course we do. He thanked me for my truthfulness, then said plainly, I want you to stop it, and I think to this day that he thought I really would. When we got home, it was understood that I would stay there. But as he went upstairs to change his clothes, my father said why don't you ever have Mimi over here? He came down a step before going back up, and added, looking at me, I'd like to meet her.

When Mimi came to our house for dinner that first time, just the three of us, my father looked her squarely in the eye and treated her with a certain humble kindness. "Humble," actually, was a word I wouldn't understand for a long time, and to be precise my father was both more and less than that. What the world took for modesty in him was not modesty at all but that proud Timesian scorn for human importance of the everyday sort. If one were great, then yes, there would be greatness in humility, but he was not, and I came to believe that he wished he were only for the joy there would be in laying greatness aside. So that first night at dinner, he poured us each a glass of his best Riesling - it was the first wine Mimi or I had ever drunk - and smiled, saying the man who lets his cellar survive him dies too soon. But the mention of death seemed to embarrass him, and he quickly hoisted his glass and said here's to you kids.

We drank, choking it down. My father was in an expansive mood, and drained several glasses along with the simple food he had cooked himself. The presence of Mimi at our table seemed to complete something inside him that had gone begging for a period of time that stretched back far beyond my mother's death, which in and of itself hadn't seemed to change him. He couldn't "look sad" any more than he could "look happy." Now he leaned back in his chair and eyed me steadfastly. No one can call me a failure, he said at length, when I've raised a good son. I suddenly felt acutely embarrassed myself, and buried my nose inside my wine glass. But Mimi set her own empty one down, and laughed tipsily as she said, you raised him good. To my amazement, my father didn't bother to correct her grammar. She put her arms around me and kissed my mouth, and for the first time that evening, he lowered his eyes.

After that, she came over to our place often, often while he was home and she could talk to him, which she did like a child, with a bold but somehow fragile avidity, and sometimes also when he was gone from the afternoon to the middle of the night. Perhaps because she had no father, she seemed to take it for granted that I had no mother, and never asked about 
her beyond the bare facts of the situation. Then one evening in spring, when my father was at work, she sat on the floor beside the black bookcase filled with children's books, looking casually through the books my mother had pored over, when she suddenly said, I love these things. My mother never read to me, she said. Her voice held no blame, but her eyes darkened in the unchanging light from the table lamp in the corner. I had never realized there were people in the world who didn't hold their children and read to them, and something went out of me. I felt like I wanted to cry, but I reached for her hand and called her my best beloved, which she only thought was a name I had made up, and drew her up to sit next to me on the sofa. I said I will read to you. She smiled cynically and said yes, daddy. I reached for an old book with a tattered binding and read each simple poem slowly aloud, with her head on my shoulder, and after I turned the last page I read, as a kind of coda, what was behind it:

The sky is blue, the sun does sink, The clouds are colored sky-blue-pink, And now with all my heart I think My love for you will never shrink.

She had been listening with her eyes closed, but now she opened them and looked at the faded piece of paper in the back of the book. She said it has your name at the top, then she looked up at me with something like fear in her eyes and said, did your mother write that to you, Ernie? Is that her name at the bottom? And before I knew why, I'd said yes, and I was crying, and she got up on her knees beside me and placed my head between her breasts and said come to Mimi.

I started kissing them through the clean-smelling T-shirt, which was wet from my tears, and she lay me down and kissed my face and neck and unbuttoned my shirt. She kissed my belly and unzipped my pants and took it all the way in, with her tongue underneath it like a soft bed, and sucked, not hard, not moving, but gentle, and still. I felt like I was a baby at the breast, only I was the breast and the sucking too, and the whole thing was me, and I never wanted it to end. But in fact it ended before it ended, because at that moment my father burst in two hours early through the garage door. He switched on the overhead light and stood drenched in its glare, knitting his brow and blinking his eyes in shame-shame not for us, but for himself. 
Woven Mann nicht sprechen kann .. . He disappeared upstairs without a word, and never mentioned it again. And things might have gone on forever for all I know if not for the Saturday after graduation two weeks later, when we stood in the kitchen and happily told my father that we wanted to move into an apartment and live together. He was wearing a flowered apron over his suit-shirt, and the room was pungent with the smell of Roquefort dressing, which he was making himself. There was a roast in the oven. He looked up at us dead-pan and said, you mean to get married? We colored and looked at each other in confusion and said no, not married, just live together. He did not look up this time, nor miss one beat of the whisk in the Mason jar, but said, you do that and you may return to this house for your mail and for nothing else as long as you live, because I disown you. We looked at each other again, disbelievingly, and I said Dadbut his face was pinched and honed as he repeated: for your mail and nothing else, as long as you live. He said make your choice.

What choice? I cried, and he said you know what choice. Mimi ran out the front door, and I said to him tremblingly, we love each other, but he said what do you children know about love, and I remember now how I stumbled in my mind and thought maybe he's right, but he wasn't, he was wrong, wrong, wrong, and I answer him today out of the fullness of knowledge: everything. We knew everything. I gave up and ran out the front door after Mimi. When I caught her there were tears streaming down her face and I said do you want to get married? She looked at me fiercely, like a falcon, and said you'd do that? I said yes, and my heart surged up with hope and joy. She said just because he says to, you'd do that? I said Mimi, why not? Why not, Mimi? She turned her head and spat on the road, and said that's why not. Then she turned and walked home. She wouldn't ever return my phone calls and as far as I know she married someone in the Navy, and lives in Maryland.

Three years ago, almost four years ago now, I was driving home alone from Heisler Park, where I'd been sitting by myself, at dusk, looking out over the ocean. I came around the curve onto Cliff Drive without my headlights, smack-dab into the shadowed face of a kid on a skateboard. I slammed on the brakes and he dove onto the gravel of the shoulder just before the board got flattened under my right front tire.

I was shaking like a leaf as I got out to pick the kid up. He said nice driv- 
ing, Dad, and my face was drenched as I lifted him bodily by the front of his shirt and held him feet down over the edge of the drop-off the road is named for, shaking him and screaming you want to die? You want to die? You want to die? He just looked at me, hanging there with his collar up around his nose, and of course he couldn't say anything. I dropped him on the road, and reached into my back seat, where I kept a piece of clothesline for tying the trunk. I threw it at him. You want to hang yourself, I shouted, I'll give you the rope. Then I got back in the car and peeled away in a shower of gravel, leaving him there in the dark, with his shattered skateboard.

We never told Ruth. She'd have wanted to talk about it, to turn it into some kind of heavy portent, and Rusty and I were comfortable with secrets. In fact, I was comfortable with what went on between him and Shyla, and more than a little annoyed with Sam Larson for the sanctimonious way he had of turning Rusty's secret over to us, but I grounded the boy for two weeks to make Ruth happy. I didn't know what else she could expect. The family counselling was her own idea. I said Ruth, what the hell good is that going to do him? and she said it's not just for him. That gave me a bad feeling. I figured if we were going to bitch and gripe at each other, why drag the boy into it? In each of us, I think (though I'm no psychiatrist), there is a secret that we want to know without really knowing, and is that so bad? But when I tried to explain this to Ruth, she only said Ernie, dear, this has nothing whatsoever to do with secrets. It has to do with what anyone can see.

That had been her credo, of course, for many years. But all I could see was secrets, even when people held them up to my face with both hands, and I wondered what Ruth's would look like, and how they would hurt me. And to tell you the truth I wasn't reassured when I saw the face of this "counselor" Ruth had found us. Her name was Victoria, and her shop, or whatever you call it, was right in the cottage she lived in alone on Glenneyre Street. Talk about secrets. Victoria had been recommended to us by no less of a normal guy than Sam Larson. He said that he and the missus had used her themselves, back in ' 87 , when he'd gotten retired, and his being around the house all the time after so many years had made his wife murderous. We'd never really loved each other, he said - he said that, straight out - and this gal, God bless her, helped us find a way to live together. Very professional: that's how Sam Larson described her. 
But when Rusty and Ruth and I sat down in her shop-office-for the very first time, she looked at me with a grin and said lighten up, guy, this isn't a hanging, and I didn't think that was very professional. Ruth and Rusty both laughed, as they knew they were supposed to, and I got the feeling they were laughing at me. Then the counselor crossed her knees and folded her hands. I'd say she was fortyish, young-looking, tanned and blonde and short-haired, wool-skirted, silk-faced, comfortably bankrolled. The face said no worries: talk, she'd heard it before. And that was exactly what bothered me at first. I felt like whatever my secrets were, she already knew them, and she couldn't care less. It had to do with what anyone could see.

Her manner of speaking - bright and broken like bits of colored glass and with a dazzlingly categorical absence of irony - put me in mind of a well-written children's book. We're all here for one reason, she said now, and everybody's is different. Rusty, you first. He smirked and said this wasn't my idea. Ruth didn't wait to be invited but said the idea - "our" idea, as she inaccurately described it - began at the ocean. I thought she must mean the ocean Shyla walked out of, but she added, on Maui, last month. Victoria said what happened on Maui? Nothing, Ruth said, I mean absolutely nothing. Victoria said I see, then she turned to me. Mr. Hoff? I said it is Mr. Hopf, like hope with an "f." When she smiled, her straight white teeth stood out like costume jewelry against her suntan. I like that name, she said, because myself, what I'm mostly into is survivorship.

Herself, she mostly did the talking that first session, which in view of her fees struck me as a needless extravagance. She told us she hailed from a family of dryland farmers in Montana - I had pictured Fifth Avenue - and knew a thing or two about adversity. I thought bully for you. She said she'd never regretted never marrying, and I guess she read my look of extreme apathy because she added that she was telling us this so we would understand that marriage was what she called the vehicle rather than the destination and she'd never pictured herself in the used car business, if we got her drift. I can't remember any more of it except certain buzz-words: trust, grief, loss, rapport, etcetera. I knew they went together in some fashion, but they sounded the way a puzzle looks in its box. Even four weeks later, when the sessions abruptly terminated, most of the puzzle pieces still looked to me like nothing more than colored fragments, and all 
our talk runs together in my mind like the border of a puzzle slowly assembling itself from both ends at once but never connecting. It's a loop of tape with no beginning or end that seems to repeat with Rusty telling Victoria we didn't "understand" him.

I remember blurting out you son of a bitch-he had jumped me with that one, imagine Rusty - when I noticed the counselor's eyes coolly upon me while her smooth face was still turned toward my son, and I shut up. Ruth started to cry (she cried very easily) and said my God, Ernie: not mad, just kind of sorry and disgusted. Rusty was looking at the rug, which was thick and unpatterned. I decided not to say another word, but everyone else must have decided the same thing and we all sat there like total strangers in a waiting room for an uncomfortably long period of time, while the clock kept ticking. Finally I said aren't you supposed to be facilitating something? Victoria laughed, very pleasantly, and said I just did. I said oh come on, we talk like that all the time. My son and I know each other, I said. Rusty was still studying the blank carpet, but he said quite clearly, that's what you think. I saw then how this "counselling" was going to go, and it made me sad. He said I may know you - he said this emphatically-but you do not know me, and you never will.

I couldn't keep the sarcasm from my voice as I said tell me something I don't already know. He looked at Victoria and said I just did. Then why are we here? I asked, thinking bitterly to myself, you want to be like that. Victoria leaned toward me with her legs crossed-it may have been the same session or it may not, she was wearing an elegant pleated tartan kilt kept from falling open over the length of her farmer's daughter's thigh by one of those oversized gold safety pins - and said do you mean here, or here? She opened her arms above her head like a world-creating goddess. I mean here, I said, where else would I mean? Here. He means here, Ruth said with a sigh, in Laguna Beach. She was slumped back wearily in the fat leather armchair. Instead of-where is it, anyway? she continued. She sounded tired, and Rusty said: Maryland.

I suddenly felt fear in the pit of my stomach. I hadn't told anyone about Maryland. My throat was dry, so that my voice sounded rough as I said, you know about that. My mother told me, Rusty mumbled sheepishly, and there was no need to ask who'd told his mother, since it hadn't been me. My father was the only other soul who'd ever known. Ruth was crying again, and twisting a handkerchief tighter than a braided rope. He told 
me you'd learn to hold me in your heart, she said, and then she had to stop. I said those were his words? She said is that so strange? He was a man, Ernie, not some molded icon. You're losing me, Victoria said, but Ruth went on as if she hadn't heard her. Those were his words, she said, but they weren't true, then she pressed the braided handkerchief to her eyes like a blindfold, and sobbed silently.

People, we've got to go back, Victoria said firmly. I looked at Ruth. I said do you want me to leave so you can explain all this? Do you want to leave? Victoria asked. Ruth sighed again, brokenly, like an escapement. He's wanted to leave for a long time, she said, but he stifles it. Victoria said we should only make "I" statements here, and Ruth said I feel like he's always wanted to leave. They were all looking at me expectantly, like it was my turn, and I found myself looking at Rusty with tears in my eyes, and Rusty looked back at me and said, he left a long time ago. You feel like he left, Victoria corrected, and he said yes, I feel that. I feel like he went to the moon, or something, he said. Victoria stared at me peculiarly-I chose to take it for a playful look full of friendly concern rather than the look of a professional counselor-and said with a smile, how'd you get to the moon? By this point - and I don't even remember which session it washer smile had come to feel like oxygen piped into a room that was as tight as a plexiglass helmet shoved down over my head. I inhaled it, and it took my voice away. In the silence, Rusty was telling of an armored van that had wings like a long-tailed jaeger and could take a person's soul to the moon while he slept. I loved that story, he said, but it made me feel like he wanted to put me in it and take me with him, and I'm not going.

But he was, and sooner than we thought, and it didn't change anything when Ruth said of course you're not. She reached over me and patted Rusty's knee and said we all have our angels, darling, and you have yours, and just see to it he doesn't take her away from you. I never intended to try; that was not my intention. I was only feeling this weird tenderness, like the ache of a new muscle: you want to flex it. After we'd been in counselling for a month, Victoria suggested it was time all the principles got together outside the system, as she put it, so Ruth and I took the kids out to dinner one night, to Claes's in the Hotel Laguna, and Shyla looked radiant in a simple tank-top. I took her hand and said Shyla - that's a beautiful name. Ruth said Ernie, the girl's not interested, and we all laughed. Shyla said I remember you at the library, you read so beautifully. She said I 
mean when I was a kid, and she actually blushed. I said were you one of the ones I held on my lap? Ruth said drop dead, old man. Rusty looked at Shyla with eyes that disowned me, as Ruth said, I mean it, Shyla, put him in his place.

We all laughed again, and I ordered a bottle of wine. As we studied our menus, I noticed the three of them eyeing each other anxiously over the candles. I said all right, I'll shut up, you can relax now. Rusty cleared his eighteen-year-old throat and said Dad, we have something important to tell you. I drank a gulp of wine and said do you have to? He said mom already knows. The waiter was there, hovering in the background, grinning broadly. I waved to him and said we're ready to order, so you can get lost. He took our orders and left, and Rusty said Dad, I have something to tell you, we're going to get married. I said who? He said Shyla and me, and the three of them tittered weakly, as if that were funny.

I felt like someone had spiked my wine with strychnine. The room had gone fuzzy and I couldn't see any faces across the table through the suddenly blinding flames of the two candles. I said I don't think you should do that. Laughter again. I said why would you want to do such a thing as that? Though I still couldn't see him, I clearly heard Rusty say Dad, we love each other, and I heard myself say what do you know about love? He said what's there to know, then somebody brought us our salads and they started eating. I couldn't believe they were sitting there eating their salads. I said why don't you just go out and live together? Who needs to get married? I said Victoria says - but for the first time in his life he cut me off and said do you think I give a damn what Victoria says?

All I heard for a moment was the sound of them munching on lettuce greens like rabbits, then Shyla explained, as far as living together, Mr. Hoff, we don't think that is right. My voice went up an octave and I said was it right, was it right for you to sleep in my bed for five fucking days? and Ruth said Ernie. I realized Ruth had been silent for a long time, and she slipped my name in quietly but sharply, like a knife. I said don't Ernie me, I won't allow it. She said you won't allow what? and I stammered marry, marrying, marriage, there will be no marriage! Then the bottom dropped out of my heart, and I sat there sobbing. Shyla must have gotten up and left, and Rusty must have followed, because when I opened my swimming eyes the candles were out and the children were no longer there. Ruth was still there, dry-eyed, not angry, but looking at me, I felt, with frank pity. 
She took my hand and said Ernie, they don't need your blessing. I removed my hand from hers, and got up and walked out.

But of course she was right. The kids got married in Tijuana, of all the unaccountable places, and spent the rest of the summer skin-diving off Baja. Rusty hasn't been in touch. He may be in touch with his mother, but she hasn't told me. She thought it best that we spend some time apart, indefinitely, and now Victoria and I are doing a one-to-one. I'm referring strictly to the counselling, of course, although as far as counselling goes, she says group is best. She says the feeling in the business nowadays is that one-to-one is just re-parenting. And we wouldn't want that.

I got something in the mail this morning from Ruth. It's a card, written by my father, dead for twelve years - an ordinary, white, unlined $3 \times 5$ card containing a list penned in my father's unmistakably legible handwriting. It's a list of chores. She asks me to forgive her for never having shown it to me before, but she says he gave it to her and not to me for reasons of his own. She says he told her it might be a useful reminder to her, as it had been to him, although he'd long since forgotten about it until he'd found it in his desk at The New York Times when he retired. He'd brought it with him to Laguna Beach that time he stayed with us when Rusty was five. She says it had been, in her words, "their little secret."

My first reaction was to be furious with Ruth for hiding this document from me for so many years. If she'd kept it forever, I might never have known how well I know this man, whose deepest wish was the wish that the heart could be repaired with a hammer and nails. Fix garage door, the list starts out. Tar driveway. Fertilize dogwoods. Have patience with Jean. And at that point my forty-year-old heart began to race with a sudden inkling that I had just sailed off the edge of the known world, as I read: Try to be more loving with Ernie. The list went on to catalog a rip in a screen door and the accumulation of dead leaves along the fence where the back lawn ran against a woods behind our house in New York, and various other deteriorations in the condition of the universe which had at that time competed with me for his attention and which I did not even bother to read this morning, because I was already wondering if to love was not to be loving, and how a father could be more so, and most especially why he had to "try," and finally to what end Ruth had belatedly caused me to trespass on a humble man's profoundest aspirations - to feel my love for my child and 
understand that this is the end, the reason, the best we can do, and at all else we really are made for failure; to know simultaneously the impossibility of ever taking what is in our hearts and putting it in our eyes or our hands, let alone our lips; to know, finally, that even if we could, he simply would not want to hear it.

I too am acquainted with the guilt of not enough love, and regarding my father, Ernest Hopf, Sr., there is little to question. He did what he could. Chiefly, I wonder if he considered his life to be wasted, because we are similar, and that's how I view my own. Not wasted, maybe, but gone wrong - grievously wrong. I remember him raising his glass of Riesling to Mimi and me and saying out loud, no one can call me a failure, and I think it would never until that moment have occurred to me that he might have been, but we were both wrong. Now my own turn has come to gaze into the bright, unscrupulous eyes of my offspring and whisper those same words into the silence, and not to believe them. I feel I am nothing anymore except Rusty's father, and now even he has gone away. I feel myself becoming less visible, and try to guess from time to time if my father ever felt the same thing, felt everything but me, his son, come to nothing, then felt me, his son, come to nothing too. Maybe that's why his answers always ended before they'd begun. They ended here-on a beach facing west, under a sky like a lacuna, empty except for clouds of sky-blue-pink.

Losing people is the purest loss. There is one, maybe two, maybe three, who are lost for good, but I think Ruth, at least, is ready to take me back I think that's the real secret of her card this morning - and I'm ready, if she is, to try to be more loving. What else can we do? Likewise, Rusty will one day return to this beach - he has to-and when he does, I'll tell him everything. Until then, as Victoria says, I'm into survivorship, and where there's that, there's hope. Without an "f." 